\title{
Negative Effects of Brand Extension
}

\author{
Tariq Jalees \\ Nadia Tariq
}

\begin{abstract}
Academicians in general, and students in particular, have recently started idealizing and romanticizing hypotheses-based empirical studies, so much so, that they incorporate hypotheses in their reports and papers, whether there is any need for them or not. In this paper, the authors have demonstrated how a non-hypothesis based research must be conducted and structured. The literature review section of this paper starts with broader concepts such as "brands", "brand image" which then have been narrowed to conceptual definitions and arguments related to brand extension, followed by arguments of different authors on negative effects of brand extensions. Subsequently, the constructs derived through literature survey have been summarized and "cited". The developed questionnaire was administered to a sample of 204 respondents, which were empirically analyzed and the results have been compared with the corresponding critical issues related to negative effects of brand extensions derived through literature survey. The results show that if brand extension is not executed properly, it will adversely affect image and sale of core brand as was the case with 7 up, when it extended to "7-up Gold". Similarly, if there is closeness between parent brand and extended brand or if extended brand is more successful, it will hurt core brand as was the case with Miller Light. If there is no associating between core brand and extended brand, then it will hurt extended brand as were the cases of extension of Ponds Tooth Paste and Colgate Kitchen Entrees are cases in point.
\end{abstract}

Keywords: Brand extension, brand equity, brand image, negative impact of brand extension.

\section{Introduction}

Failure rate for a new launch in eighties was as high as 35\% (Montoya-Weiss \& Calanone 1994 ) which reached a high of $80 \%$ (Crawford, 1997) by nineties. In view such a high failure rate of new products, brand extensions are now being as alternate growth strategies. According to Aaker (1991) using an established name of one product class for entering another product class is known as brand extension. Kotler(1991) defines brand extension as using a successful brand name for launching a new or modified product or line is known as brand extension strategy (Kotler 1991). Some of the common reasons for using brand extension as a growth strategy are that launching cost of brand extension is comparatively less because consumer are generally aware of brand, and in most of the cases, existing distribution network is used for extended brand.

Tariq Jalees is Associate Professor at PAF-KIET, tariquej2004@yahoo.com Nadia Tariq is an MBA student at PAF-KIET, Karachi.

Journal of Independent Studies and Research - MSSE

Volume 8

Number 1

January $2010 \mid 53$ 
Brand extension may also adversely affect the brand name that happens to be the most important asset of any company. Wrong extension, not only results in substantial loss of time and other market opportunities, but it may also lead to the "damaging association that may be expensive or even impossible to change" (Ries \& Trout 1986). However, the failure rate of extended brand has also increased quite significantly. In view of this failure rate of extended brands, academicians have started investigating the negative effects of brand extension.

Academicians in general, and students in particular, have started idealizing and romanticizing hypothesis based research, whether there is need for it or not. The purpose of this study is to demonstrate that non-hypothesis based study could be as effective, if not more, as hypothesis based empirical study. Moreover, this study would also demonstrate how non-hypothesis based studies should be structured. The literature survey in this study starts with broader concepts that have been narrowed down to core issues of the study that is negative impact of the brand extensions. While deliberating the arguments of different authors on negative effects of brand extension, an attempt has been made to incorporate at least one real life example of brand extension failure to substantiate the claims of different authors. While doing the analysis, it has also been demonstrated whether there is difference in the findings of this study and studies that have been previously carried out. Moreover, while synergizing data, literature survey; an attempt has also been made to augment the arguments by incorporating at least one real life example of brand extension failure.

\section{Literature Survey}

\subsection{Brand}

Kotler and Armstrong (2007) has defined brand as a name, term, sign, symbol, design or a combination of these attributes used by the firms for identifying their products and to differentiate the competitor's brands. Another important aspect of brand is that it helps consumers in identifying the manufacturers (Kotler and Armstrong, 2007). The scope of branding is beyond product identification. Brands not only reflect quality but it helps in creating competitive advantage and helps customers in making purchase decisions (Kapoor, 2005). Keller (1998) also adds that branding should be used for creating brand awareness and developing associations in accordance with firm's strategic goals.

Branding has two perspectives. One is product plus view and the other is holistic view. In product plus view, brand is perceived as an addition to the product; therefore, it is also termed as an identifier. In holistic view, the scope of brand is not restricted to product. In fact, in holistic view, it is a reflection of all the 4 ps of the marketing mix. Brand, besides offering product, contains certain attributes that may provide satisfaction to purchaser. These attributes are not restricted to tangibility or rationality but are inclusive of intangible or invisible features (Ambler and Styles, 1996). 


\subsection{Brand Equity}

Brand equity is a relationship between customers and brands, resulting in a profit to be realized at a future date (Wood 2000). Kotler and Armstrong (1996) were of the opinion that measuring brand equity is a tedious job. Nevertheless, a powerful brand means high brand equity that helps in achieving 'higher brand loyalty, name awareness, perceived quality, and strong brand associations'. Some of the major benefits of brand equity are brand awareness and consumer loyalty, which help in reducing marketing costs. Brand is an important equity; therefore, it should be carefully preserved by adopting strategies that would help in maintaining or improving brand awareness, perceived brand quality and positive associations. (Kotler and Armstrong, 1996). Ambler and Styles (1997) are of the opinion that brand equity could be measured from two perspectives. One is "financial evaluation approach" and the other is "consumerbased approach". The financial evaluation approach is related to monetary value of brand, and the consumer-based approach focuses on brand itself, that is, how much value consumers give to brand. Brand equity is also considered as an accumulated profit that could be realized at a future date. The brand equity concept can also cause confusion, because of the difficulty in measuring it (Amler and Styles, 1997). Investment and brand equity both have a limited life. Brand equity cycle is comprised of growth, reinforcement or decay, and is vulnerable to competitors. Organizational actions have a direct bearing on brand equity. Strong brand equity also helps in reducing introduction cost of new brands. (Pitta and Katsanis, 1995).

\subsection{Brand Extension}

Some of the commonly used definitions of brand extensions are as follows: Using an established name of one product class for entering another product class (Aaker 1991). Using a successful brand name for launching a new or modified product or line is known as brand extension strategy (Kotler 1991). An expansion strategy in which firms use already established and successful brand name for introducing a new or modified product (Kotler and Armstrong, 1990). Using an established brand name for introducing a new product into product category which is new to the company is known as franchise strategy (Hartman, Price and Duncan, 1990).

When a firm uses the existing brand name for extending into a new product in the "same product class or to a product category new to the company" it is considered as horizontal extension (Pitta and Katsanis, 1995). Horizontal extension again could be extended into two categories. One is line extension and other is franchise extension. Aaker and Keller (1990) states that horizontal brand could be further divided into two categories, which are line extension and franchise extensions, and according to them the focus of these brand categories is different (Aaker and Keller, 1990). Using an existing brand name and same product class for entering a new market segment comes in the category of line extension. Examples of line extensions are Pepsi and Diet Pepsi (Aaker and Keller, 1990). Other examples of line extensions are shampoos for different segments such as dry hair, oily hair, and dandruff hairs, etc. This strategy is generally more successful for extensions in the same category as the core product. Franchise extension, 
on the other hand, is a strategy of using current brand name for entering a product category that is new to the company (Tauber 1981).

\subsection{Negative Impact of Brand Extension}

Using equity of a brand to leverage into different product category may be profitable, but it has its share of risks as well. Some of the very common risks associated with brand extensions are (1) a high number of brand extensions tend to adversely affect value associated with brand, and (2) brand extension that fails to make an impact may dilute equity of a reputable brand name (McCarthy, 1996). John, Loken, and Joiner (1998) in this context are of the opinion that if brand extension fails, it would adversely affect core brand.

In this context "Colgate Kitchen entrees" is one of a few real life examples to support the findings of John, Loken and Joiner (1998) and other researchers. Colgate, when extended to "Colgate Kitchen" not only it failed miserably but also, adversely affected the sales of parent brand i.e. toothpaste. Some academicians are of the opinions that the premise for extending in toothpaste category was that consumers would eat Colgate meal and brush their teeth with Colgate Tooth Paste (Haig, 2004). Ries and Trout (1986) while endorsing the preceding opinions stated that even if the brand is used "congruously", the success to extended brand would be at the expense of parent brand.

Aaker and Keller (1990) in this context found that the brand extension may carry typical attributes of parent that may be dangerous to extended brand. Thus, Aaker and Keller (1990) were surprised that respondents' thought that Crest Chewing Gum, a brand extension of Crest tooth paste would taste typically like toothpaste or may not be appealing. Similarly, Life Saver, which was invented in 1912, is one of the leading and favorite brands of sweets in the United States. The Life Savor Candy that comes in different flavors of hard roles candies has an estimated production of 3 million roles per day. However, when it extended to "Life Saver Soda" it failed miserably as consumer thought that they would be drinking liquid candy (Haig, 2004). Consumer perception was that this extension would carry the traits of the core brand.

Similarly, Pond Cream's extension in the "tooth paste category" also failed. Consumer perception about Pond Cream was related with "fragrance, freshness and external application" which does not match with toothpaste whose main attribute is with "taste" (Haigh, 2004). Loken and John (1993) in a similar research found that the possibility of dilution in brand extension cases increases when there are higher degrees of inconsistency between parent brand and extension brand. Loken and John (1993) found that when consumers' perception towards brand extension is weak, this perception will also be transferred to parent brands and hence they would believe that attributes of parent's brand are weak as well. (Shocker, Srivastava and Rueker, 1994) If brand extension is not executed properly, it would not only damage corporate associations but would have several other adverse impacts (Ries and Trout 1986; Loken and Roedder, 1993). When Seven Up extended to Seven-Up Crown in the year 1998, 
it had positive impact on the sales in the short run, but it adversely affected the sales of the core brand. According to an estimate, it has reduced the sale of the core brand by $50 \%$. The reason for such dilution effect was that it was not properly executed. Contrarily, Coca-Cola Diet is one of many examples of properly executed extensions. It neither canalized the parent brand, nor affected its sales. It kept on growing and ColaDiet is now ranked third in the popularity list and has estimated annual sales of more than one billion. (Haig, 2004).

Another risk associated with brand extension is the cannibalization effect. The gravity of cannibalization would be higher for (1) those brand extensions that are more successful in new brand category, and (2) for those extensions that have higher degree of "closeness" between parent brands from consumers' perspective. (Sharp, 1993 and Farquhar, 1990). In 1970, the brand image of Miller Core Brand "Miller High Life was considered as the "Champaign of Beer" the company had used endorsement of Jazz Musicians to position this brand as "sophisticated personality", without much success. One of the reasons for its failure was that it was mainly targeted to women and upper income group, who are not known to be beer drinker. Miller High Life had created this personality, because it wanted to differentiate with Budweiser and Coors Beer that have macho image.

In this context, there was an example in which Marlboro cigarette had replaced image of female smoker with "Iconic Marlboro Man" and were successful. Taking cue from Marlboro, Miller high life repositioned itself as "masculinity" and all its advertising campaign at that time was to "Out Macho" its rival, thus by 1997 it became the second most popular beer in the country. Miller successfully extended to "Miller Lite" a low calorie beer without affecting the "macho image". It had positive image on the sale of core brand in the short run, but in long run its sales declined significantly (Haig, 2004). The success of extended brand in this case was at the cost of core brand, which should not be brand extension strategy.

Reputed brand extensions at times fail. This failure could generate following adverse feelings for parent brands: (1) customers may feel that brand extension is not adding value to product, and (2) it is an exploitation strategy, in general and specially for increasing prices (Aaker and Keller 1990). Failure of extended brand hurts core brand, especially if there is inconsistency between parent and extended brand. In this context, the customers did not find any association between Levi tailored Classic, a line of men suiting that was sold separately, and the old and strong perception that Levi's products are casual living and are of rugged material (Aaker and Keller 1990).

In this context, a company founded in 1869 is one of the leading food company carrying 57 varieties of food including baked beans, soups and ketchup. In 1980, it extended into "all cleaning vinegar". However, extended brand failed miserably. One of the reasons for the failure of extended brand was that Heinz was a food company with a strong image. If the company produces vinegar, "consumers would expect to pour it over the meal". The last thing they would expect to be "sitting along side of the bottle of bleach and household detergent". Thus vinegar and Heniz are both edible, and the cleaning 
vinegar had confused consumer. Another example on this issue is of "Bic" which is more known for marketing disposable cigarette lighter, and safety razor. In view of the fact that both of their products were disposable, the company came up with a unique extension of disposable underwear (panty house). The logic from the company perspective was again, that it comes in the category of "disposability" and existing distribution could be used for marketing the same. However, the extended brand "Bic Underwear" failed miserably, as consumer could not find any relevance between the core brands disposable razors/lighter and extended brand disposable underwear (Haig, 2004). Similarly, Ben-Gay, an analgesic cream is primarily used for arthritic pain, muscles aches and back pain. It is one of the leading brands of the United States. The company then thought of extending into Ben-Gay aspirin. The logic for this extension was that both Ben-Gay cream and Ben-Aspirin is pain reliever, and the existing network could be used for launching Ben-Gay Aspirin Brand. However, the brand extension failed miserably. One of the reasons for the failure was that Pain-Gay Cream has such a strong association with cream, that consumer could not imagine swallowing Ben-Gay product, even if it happens to be an oral medicine like aspirin ((Haig, 2004).

\section{Methodology}

Based on literature survey several constructs were derived which were used for developing the questionnaire that was based on Likert scale (5 to 1), with five showing very high agreement, and one showing very high disagreement. Additionally, the questionnaire also contained eight questions related to personal data, which were based on nominal scale.

The summary of the construct used for developing the questionnaire is presented below:

- $\quad$ Failure of brand Extension will adversely affect the value associated with the Brand. ((McCarthy, 1996).

- $\quad$ Brand extension may carry typical attributes of parent that may be dangerous to extended brand. (Aaker and Keller 1990)

- $\quad$ Brand extension, if not executed properly, would damage corporate brand (Ries and Trout 1986; Loken and Roedder 1993).

- Successful or extensions that have a high level of closeness with core brand would cannibalize core brand (Sharp 1993; Farquhar 1990)

- If there is no association between parent brand and core brand, it will have negative impact on extension (Aaker andKeller, 1990).

The questionnaire was administered to a sample of 204 consumers. Quota sampling was used for drawing samples. The data collected were analyzed, and cross referred with literature survey. Results of the survey findings were substantiated by real life examples of brand extension failures. 


\section{Results and Discussions}

\subsection{Failure of Brand Extension and its Negative Impact on Brand Extension}

Researchers have diversified opinions on failure of brand extension and its impact on parent brand. The respondents' opinion on this aspect is presented below:

Table number-1

\begin{tabular}{|l|c|c|}
\hline & No & Percentage \\
\hline Very High & 18 & $8.82 \%$ \\
\hline High & 32 & $15.69 \%$ \\
\hline Neutral & 118 & $57.84 \%$ \\
\hline Low & 20 & $9.80 \%$ \\
\hline Very low & 16 & $7.84 \%$ \\
\hline & 204 & $100.00 \%$ \\
\hline
\end{tabular}

Graph-1

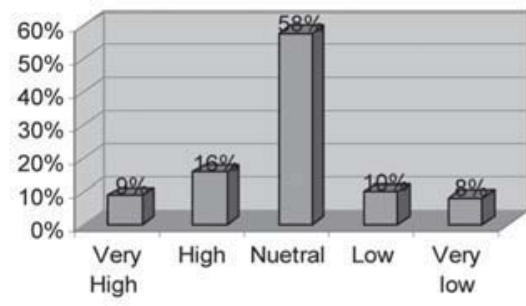

About $57 \%$ of the respondents had no opinion on this issue and about 24 of the respondents were of the opinion that failure of the brand extension will affect parent brand, and the rest 17 were of the opinions that it will not adversely affect parent brand. Comparatively, McCarthy (1996) was of the opinion that failure of the brand extensions may have negative impact on the reputation of brand extension. Loken and John (1993) were of the opinion that when the consumers' opinion about the brand extension is weak then there perception will also adversely affect the parent brand. As already discussed in the literature survey, Colgate when extended to "Colgate Kitchen" not only it failed miserably but also adversely affected the sales of parent brand i.e. toothpaste(Haig, 2004).

\subsection{Parent Brand Attributes in Extended Brand}

The literature survey suggests that when strong brands are extended into other categories, consumers may perceive that the attributes of parents' brands have been transferred into extended brand. The summarized results are presented below:

Table-2

\begin{tabular}{|l|c|c|}
\hline & No & Percentage \\
\hline Very High & 106 & $52 \%$ \\
\hline High & 48 & $24 \%$ \\
\hline Neutral & 16 & $8 \%$ \\
\hline Low & 18 & $9 \%$ \\
\hline Very low & 16 & $8 \%$ \\
\hline & 204 & $100 \%$ \\
\hline
\end{tabular}

Graph

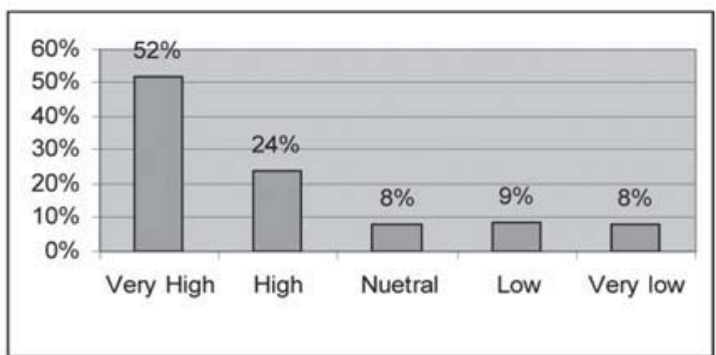


Majority of the respondents $(76 \%)$ showed a high level of agreement on the premise that if core brand is strong, then there is more likelihood that consumer may perceive that extended brands have the same attribute of parent brand and may result in the failure of the extended brand. Our finding supports the findings of Aaker and Keller (1990) where they found that consumers have a perception that Crest Tooth paste, if extended to Chewing gum will taste like a tooth paste. Similarly, Life Savor Candy when extended to "Life Saver Soda" it failed as consumer had an impression that they would be drinking liquid candy. Similarly, Pond Cream's extension in the "tooth paste category" also failed. Consumer perception about Pond Cream was related to "fragrance freshness and external application," which does not match with tooth paste whose main attribute is with taste.

\subsection{Execution of Brand Extension Vs Parent Brand}

The literature survey suggests that if brand extension is not executed properly, it will adversely affect the image of core brand. The respondents' opinion on this issue is summarized below:

Table-3

\begin{tabular}{|l|c|c|}
\hline & No & Percentage \\
\hline Very High & 84 & $41 \%$ \\
\hline High & 84 & $41 \%$ \\
\hline Neutral & 18 & $9 \%$ \\
\hline Low & 12 & $6 \%$ \\
\hline Very low & 6 & $3 \%$ \\
\hline & 204 & $100 \%$ \\
\hline
\end{tabular}

Graph-3

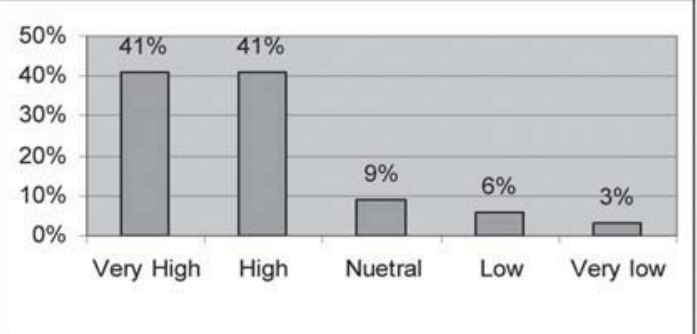

Majority of the respondents (82\%) had high/very high opinion on the premise that if brand extension is not executed properly, it will have an adverse impact on core brand. Riest and Trout (1986) and Loken and Roedder (1993) findings are similar to our findings which are that if brand extension is not executed properly, it would not only damage corporate association but would have several adverse impacts.

Seven Up, when extended to 7 Up Gold-a variation of the core brand-it adversely affected the sale of the core brand by $50 \%$. One of the reasons was that it was not properly executed. Contrarily, Coca-Cola diet is one of many examples of properly executed extensions. It neither canalized the parent brand, but it kept on growing and is now ranked third in the popularity list with an estimated annual sale of more than one billion dollars (Haig, 2004).

\subsection{Brand Extension and Cannibalization Effect}

Respondents' opinion on the issue of brand extension and its canalization effect on 
parent brand were also taken. The summarized results are presented below:

Table-4

\begin{tabular}{|l|c|c|}
\hline & No & Percentage \\
\hline Very High & 18 & $9 \%$ \\
\hline High & 102 & $50 \%$ \\
\hline Neutral & 48 & $24 \%$ \\
\hline Low & 20 & $10 \%$ \\
\hline Very low & 16 & $8 \%$ \\
\hline & 204 & $100 \%$ \\
\hline
\end{tabular}

Graph-4

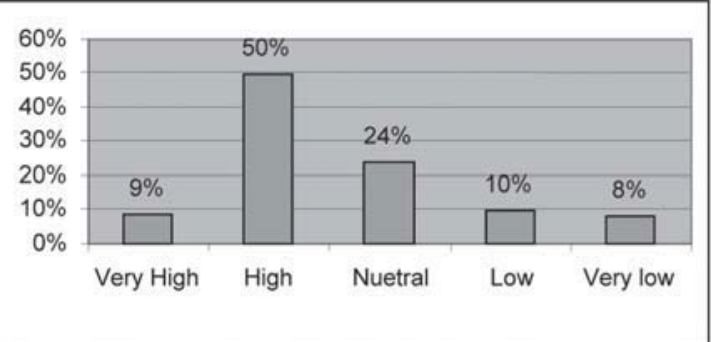

About $59 \%$ of the respondents had high/very-high opinion on the premise that brand extension would have a canalization effect on core brand. These findings again are in line with the findings of Sharp (1993) and Farguhar (1990) who were of the opinion that, if brand extensions are successful, it will affect the sale of the core brand, especially if there is high level of closeness between core and extended brand. In this context, when Miller High Life, extended to Miller Lite, the extended brand was successful, and the core brand was adversely damaged.

\subsection{Association And Negative Impact}

The literature survey suggests that association between parent brand and extended brand affects the image or success of the extended brand. In this context, respondents' opinion is summarized below:

Table-5

\begin{tabular}{|l|c|c|}
\hline & No & Percentage \\
\hline Very High & 40 & $20 \%$ \\
\hline High & 86 & $42 \%$ \\
\hline Neutral & 50 & $25 \%$ \\
\hline Low & 24 & $12 \%$ \\
\hline Very low & 4 & $2 \%$ \\
\hline
\end{tabular}

Graph-5

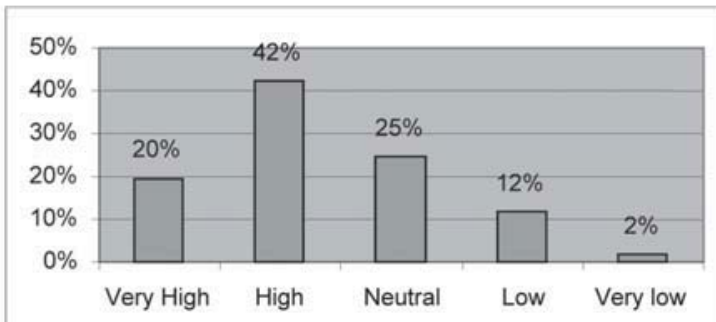

Majority of the respondents $(86 \%)$ had high/very high opinion on the premise that if there is no association between the parent brand and the extended brand then there will be negative impact on extended brand. In this context, the customer did not find any association between Levi tailored Classic, a line of men suiting that was sold separately, and the old and strong perception that Levi's products are casual living and are of rugged material (Aaker, 1990). 
When Heinz a leading food company carrying 57 varieties of food including baked beans, soups and ketchup extended into "all cleaning vinegar", it failed miserably. Heinz was a food company with a strong image, and consumer did not find any association between core brand (food) and cleaning vinegar. Similarly, Bic more known for marketing disposable cigarette lighter, and safety razor, when expended to disposable underwear failed miserable, as consumer could not find any relevance between core brands disposable razors/lighter and extended brand disposable underwear (Haig, 2003)

In this context, when Ben-Gay, an analgesic cream extended to Ben-Gay aspirin it failed miserably. One of the reasons for the failure was that Pain-Gay Cream has such a strong association with cream that consumer could not imagine swallowing Ben-Gay product, even if it happens to be an oral medicine like aspirin.

\section{Conclusion}

Brand extension strategy since last two decade has been very commonly used for expansion and growth, but failure rate of the same in recent years have also increased quite significantly. Brand extension, if not executed properly, will adversely affect the image and sale of core brand as was the case with 7 Up when it extended to 7 Up Gold. Similarly, if there is closeness between parent brand and extended brand or if extended brand is more successful, it will hurt core brand as was the case with Miller Light. If there is no associating between Core brand and extended brand then it will hurt extended brand as were the cases of extension of Ponds tooth Paste and Colgate Kitchen. 


\section{References}

Aaker, D. A. (1990), 'Brand Extensions: The Good, The Bad, and The Ugly,' Sloan Management Review, Vol. 31 (Summer), pp. 47-56.

Aaker, D. A. (1991), Managing Brand Equity: Capitalizing on the Value of a Brand Name, New York: The Free Press and Kevin Lane Keller (1990), "Consumer Evaluations of Brand Extensions," Journal of Marketing, Vol. 54 (January) pp. 27-41.

Aaker, D. A. and Keller K.L. (1990), 'Consumer Evaluation Brand Extension,' Journal of Marketing, Vol. 54 (January), pp. 27-41.

Ambler, T., and Styles, C. (1997), 'Brand development versus new product development: toward a process model of extension decisions,' Journal of Product and Brand Management, Vol. 6, No. 4, pp. 222-234.

Farquhar, P. (1990), 'Managing brand equity,' Journal of Advertising Research,(August/September), Vol. 30, pp. $7-12$.

Haig, M., (2004), 'Brand Failure: The Truth about the 100 Biggest Branding Mistakes of All Time', London: Hogan Pages.

Hartmen, C. L., and Price L. L., and Duncan P. C., (1990), Consumer evaluation of franchise extension products: A categorizing processing perspective, Advances in Conquer Research, Vol. 17, pp. 120-127.

John, D. R., Loken, B. and Joiner, C., (1998), The negative impact of extensions: can flagship products be diluted? Journal of Marketing, Vol. 62 (January), pp. 19-32.

Kotler, P. and Armstrong G., (1990), Marketing an Introduction, NJ: Prentice-Hall, Inc.

Kotler, P., (1997), Marketing Management, USA: Prentice Hall, Inc.

Kotler, P. and Keller K. L., (2007), Marketing Management, Delhi: Dorling Kindersley.

Kapoor, H., (2005), Competitive Effects on the Evaluation of Brand Extension. PhD Dissertation. Eric Sprott School of Business. Faculty of Public Affairs and Management, Carleton University, Ottawa, Ontario.

Keller, K. L., (1998), Strategic Brand Management. USA: Prentice Hall, Inc.

Tauber, E. M. (1981), 'Brand franchise extension: new products benefit from existing brand names,' Business Horizon, Vol. 24, pp. 36-41.

McCarthy, M. S., (1996), Factors Affecting Brand Extension in Competitive Market. PhD Thesis, University of Pittsburgh 
Montoya-Weiss, M. M. \& Calantone, R. 1994. Determinants of new product performance: a reviewand meta-analysis. Journal of Product Innovation Management, 11 (November), pp. 397-417.

Loken, B. and John, R. D., (1993), 'Diluting brand beliefs: when do brand extensions have a negative impact?' Journal of Marketing, Vol. 57 (July), pp. 71-84.

Ries, A. L., and Trout. T., (1986), Positioning: The Battle for Your Mind, New York: McGraw-Hill.

Sharp, B., (1993), 'Managing brand extension,' Journal of Consumer Marketing, Vol. 10, No. 3, pp. 1117.

Shocker, A. D., Srivastava, R. K. and Ruekert R. W. (1994), 'Challenges and opportunities facing brand management: an introduction to the special issue,' Journal of Marketing Research, Vol. 31, pp.149-158. 